\title{
国際的に通用する技術者に求められる 英語コミュニケーション力の開発
}

Developing English Communication Expertise for Engineers in the Global Age

\author{
小 野 義 正 ${ }^{* 1}$ 森 村 久美子 ${ }^{* 1}$ \\ Yoshimasa A. ONO Kumiko MORIMURA
}

\begin{abstract}
This paper discusses contents and results of a new graduate course "English for Engineers and Scientists" given at School of Engineering, The University of Tokyo. This course is a new attempt to develop English communication expertise for engineering graduate students: how to write technical papers and how to make technical presentations in English. For these purposes, differences in the writing styles and in the sentence structures of English and Japanese are stressed: conclusions come first in English versus conclusions come last in Japanese; the three-step style of introduction, body, and conclusion in English versus the four-step style of ki-sho-ten-ketsu in Japanese. In addition, proper styles of technical papers (rhetoric) and related grammatical points are discussed. Technical presentation course consists of four-week lecture and seven-week practice session. In the lecture, essential points of technical presentations in English are discussed in detail, and in the practice session students' presentation skills are improved through guidance and instructions given by native-speaker moderators. The class evaluation results show that most students have obtained necessary skills of technical presentation, indicating that the combined course of lecture and practice session is essential for training students to make better technical presentations in English.
\end{abstract}

Keywords : English Communication, English for Engineers and Scientists, Direct Translation from Japanese to English, Translate from Japanese to Japanese first, and then Translate it into English, English Three-step Style of Introduction, Body, and Conclusion, Japanese Four-step Style of Ki-sho-ten-ketsu, Leggett's Trees, Technical Presentations in English, Eye Contact, Questions and Answer Sessions

キーワード : 英語コミュニケーション, 科学・技術英語, 直接翻訳, 和文和訳, 英語は三拍子 (イン トロダクション, ボディ, コンクルージョン), 日本語は四拍子 (起承転結), レゲットの樹, 英語口頭発表, アイコンタクト, 質疑応答セッション

\section{1.はじめに}

英語で論文を書いたり ${ }^{1)-4)}$ 口頭発表をしたりする ことは ${ }^{5)-9)}$, 研究者・技術者にとって研究・開発そ のものと同じくらい重要である. しかし，その重要性 は認識されていたものの, 学部及び大学院での系統的 な教育プログラムが整備されていなかった，英語によ る表現力はコツを押さえて訓練すれば上達し, 誰でも 英語を母国語とする研究者・技術者にわかってもらえ る論文執筆，口頭発表ができるようになる.

論文原稿を「日本語の発想」で書き，それを英語に 直接翻訳したものはたとえ英語が文法的に正しくて

平成 19 年 11 月 2 日受付

※ 1 東京大学大学院工学系研究科
も, こちらが伝えたいことがなかなかわかってもらえ ないということがしばしば起る。これは「日本語の発 想」と「英語の発想」の違いに起因することが多い. この「英語の発想」と英文作成のルールを知り, 英語 に対するセンスを磨くことで, 正しいわかりやすい英 語論文が書けるようになる。

一方, 研究成果を世に問うにあたって英語での口頭 発表（プレゼンテーション）が果たす役割は小さくな い. ところが日本ではプレゼンテーション技法の習得 が教育システムに組み込まれておらず，プレゼンテー ションの仕方がわかっていないだけでなく, 基本的な マナーさえ身に付けていないまま行われる発表がよく 見かけられる。これでは素晴らしい発表内容でも英語 を母国語とする研究者・技術者によく理解してもらえ 
ない.

英語という言語の問題を除いても，それ以前に人前 で「話す」ということ自体が苦手な日本人は多い，日 本人の多くは「口数多くぺらぺら」しゃべることをよ しとしない風潮があり, 活躍中の研究者の多くは話す 訓練はほとんどなされていなかったに等しい. 従って, 基本的な口頭発表のスキルを学ぶことの重要性は大き い.

これらの目的に対し, 東京大学大学院工学系研究科 では2003年度夏学期から大学院共通講義「科学・技術 英語 $\mathrm{A}, \mathrm{B}$ 」を開講し, 科学・技術英語論文の書き方, 英語口頭発表（プレゼンテーション）の心得について 講義・演習を行っている. 特に口頭発表に関しては, 講義と演習をセットとしたことで，講義で学んだこと を演習で身につけることができるようになった。

本論文では，この 4 年間の経験を踏まえ，理工系学 生への効果的な科学・技術英語論文の書き方, 英語 口頭発表の仕方の具体的な教育手法と成果を報告す $3^{10), 11)}$.

2. 大学院共通講義「科学・技術英語 $A, B\rfloor$ 概要

講義は, 各 1 単位の 2 つの部分から構成され, 夏学 期と冬学期に開講されている.

(1) 科学技術英語 A：講義（8 週間）

(2) 科学技術英語 $B$ : 演習 ( 7 週間)

前半の講義 $(\mathrm{A})$ では, 科学・技術英語論文の書き方, 英語口頭発表の心得を講義し, 後半の演習 $(\mathrm{B})$ では英 語のネイティブ講師による英語口頭発表の演習を行っ ている.

\section{3.「科学技術英語論文の書き方」の講義内容}

英語論文の書き方の講義内容を図 1 に示す.

工学系の日本人学生に正しい科学・技術英語を教え るにあたって最初にきちんと教えるべきポイントは, 2 の「日本人英語の欠点と改善策」, 3 の「直接翻訳 はするな $\Rightarrow$ 和文和訳せよ」，4の「わかってもらえる
1. 科学-技術英語 (Technical Writing in English)とは
2. 日本人英語の欠点と改善策
3. 直接翻訳はするな $\Rightarrow$ 和文和訳せよ
4. わかってもらえる論文は英語の発想で (日本語と英語の発想の違いに注意) (Leggett's Trees)
5. 英語論文執筆のフローチャートと基本的な注意
6. 英語論文の構成と各項目の書き方
7. 辞書の使い方
8. 明確な英語論文を書くテクニック(作文技術)
9. 英文を書くときに心得ておくべき文法的事柄
10. チェックリスト
11. 参考文献·参考書

図 1 「科学・技術英語論文の書き方」の講義内容
論文は英語の発想で」である。これらをまとめると，

（1）日本語で書いた論文を直接翻訳するな

(2) 和文和訳せょ: Translate from Japanese to Japanese first, and then translate it into English.

(3)「英語の発想」で論文を書け（Leggett's Trees）

（4）英語の基本は三拍子：Tell'em Three Times Approach

となる ${ }^{4)}$.

図 2 に示した「日本人英語が通じない理由」を認識 し，改善策を示すことを講義の最初に強調している.

「英語の発想」が「日本語の発想」とどう違うかに ついて明快にパターン化して示したのはLeggett ${ }^{12), 13)}$ である. 図 3 に「文の構造と文章の流れ（Leggett's Trees)」を示す.

違いを説明すると

（1）日本語文の論理 $(\mathrm{J}$ 型 $)$ :説明（修飾などの副文章） が先に来たり, 複数の思考を関連させながら, 本 筋（主文章）へ合流させる

(2) 英語文の論理 (E型) : 本節 (主文章) がまずあって, 脇道 (修飾などの副文章) へそれる場合はその時 点で副文章であることを明確にしながら進める

となる。これは以下に示す日本語と英語の考え方の違 いによるものである.

1）日本語：考えをいくつか述べるにあたり，それ らの相互のつながりや, ある特定の考えの意味が, そのパラグラフ全体あるいは論文全体を読み終え てやっと明確になるような書き方をしても OK.

2）英語：それぞれの文章は，すでに書かれている

1. 日本語の文の構成を変えず, 一語一句 そのまま訳している

2. 抽象的な, 拡張の高い単語を使いたがる

3. 受動態を多用する

4. 一文が長く, 構文が複雑である

5. 逃げの余地を残しておく

6. 意味のない儀礼的表現が多い

7. 察してくれることを期待する

8. 事実と意見の区別がつかない

図 2 日本人英語が通じない理由

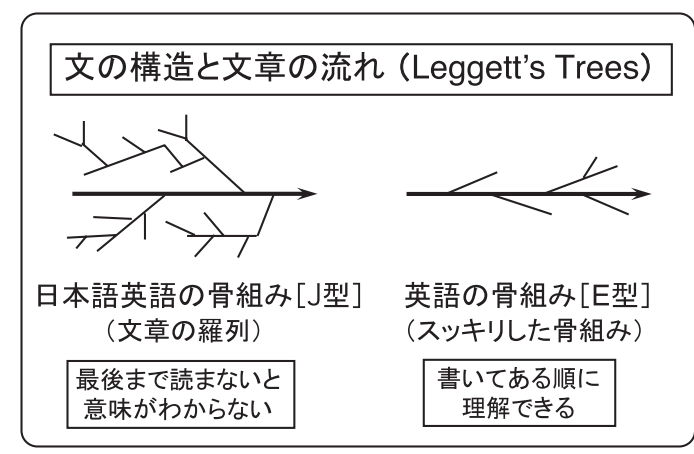

図 3 「日本語の発想」と「英語の発想」の違い 
ものだけに照らして完全に理解できなければなら ない，その上,一つの考光次の考えとの関係は， それを読んだときに完全に明確でなくてはならな い.

Leggett's Treesの例として, 実験の記述の文とそ の構造を図 $4 \mathrm{a}$ ( $\mathrm{J}$ 型), 4 b (E 型) に示す. J 型では, 周辺から説明を始めており, なかなか主題にたどりつ かないが，E型では，最初に主題を述べている，英語 論文は $\mathrm{E}$ 型の書き方をしなくてはならない.

この違いは図 5 に示すように, 日本語の構造と英語 の構造の違いに起因している ${ }^{14)}$.

すなわち日本語では重要なこと（結論）は最後に述 べるが，英語では最初に述べる必要がある，さらに図 6 に示すように, 英語の論理展開は三拍子であり, 日 本語の論理展開（起承転結）とは異なるので, 日本語

(1) In this connection, (2) at room temperature,

(3) at the measuring frequency $10 \mathrm{kHz}$,

(4) with Au-electrodes evaporated on the whole area of the crystal surfaces, (5) the dielectric constant and, (6) at the same time, (7) the loss tangent were measured.

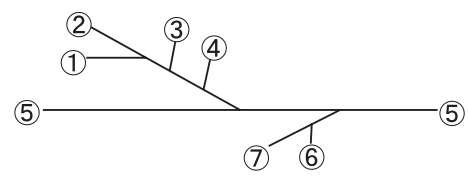

図 4 a Leggett's Tree の例（J 型）

(1) Measurements were made on the dielectric constant of the crystal (2) at 10 $\mathrm{kHz}$, (3) with electrodes evaporated on the whole area of both surfaces, (4) at room temperature. (5) The loss tangent was simultaneously measured.
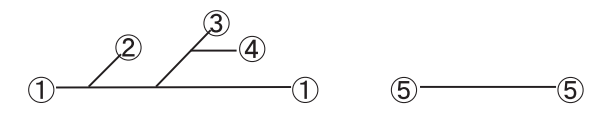

図 4 b Leggett's Tree の例（E型）

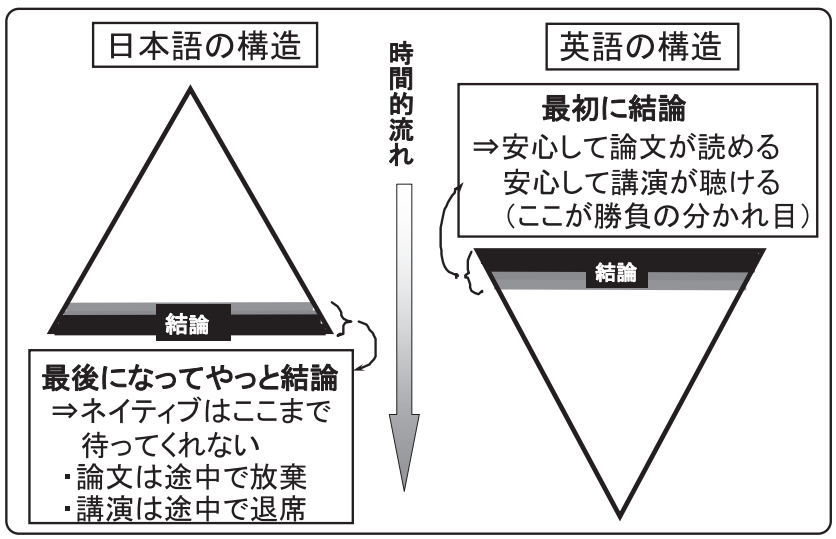

図 5 日本語の構造 $(\triangle$ 型 $)$ vs. 英語の構造 $(\nabla$ 型 $)$
で書いた文章をそのまま英語に翻訳しても，論理的な 英語にはならない.

したがって, 英語が母国語の研究者・技術者にわかっ てもらうためには, 英語論文も英語口頭発表もこの形 式に従う必要がある。

実際の論文の書き方については，図 7 に示すような IMRAD方式というきまった形式に沿う必要がある ${ }^{3)}$.

I : Introduction, M : Materials and Methods,

$\mathrm{R}$ : Results, A : and, D : Discussion である。

次に英語論文用の英語のスタイルについて議論す る. 図 8 に「明確なわかりやすい英語論文を書くテク ニック (作文技術)」として10項目をあげた.

これらは英語論文作成のレトリックに相当するもの

\section{論理的な英文は}

Introduction (導入部) -- Topic Sentence Body（本体部分）-- Supporting Sentences Conclusion（まとめの部分）

-- Concluding Sentence

の三つの要素から構成される.

日本語の論理展開 (「起承転結」) は英語圏の人間 には理解し難い。(英語では「転」のない文章展開)

$$
\checkmark \begin{aligned}
& \text { 日本語の文章をそのまま翻訳しても, } \\
& \text { 論理的な英語ににはならない. }
\end{aligned}
$$

図 6 英語の基本は三拍子

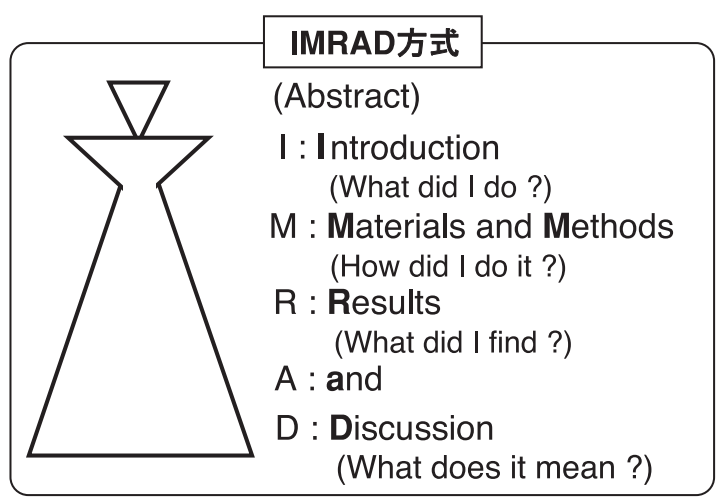

図 7 英語論文の構成
1. 文頭(Beginning of a Sentence)
2. 数 (Numbers) と数值 (Numerical Values)
3. 用語の統一, リスト項目の一貫性, つづりの統一
4. 短い, 簡潔な文 (Simple Sentences)を書く
5. 受動態を避け, 能動態を使う
6. 修飾する節や句は修飾対象のすぐ近くに
7. 文意を明確にする言葉 (連結語)を使う
8. 不必要な単語·表現を省く
9. よく使われる略語
10. 注意すべき単語·熟語

図 8 明確な英語論文を書くテクニック（作文技術） 
で，わかりやすい科学・技術英語表現にするための技 法である。 さらに，科学・技術英語の文法として注意 すべき点を「英文を書くときに心得ておくべき文法的 事柄」として図 9 にまとめた。ここで述べる文法はテ クニカルライティングの特徴である「誰が読んでも同 じ理解をする」ために必要なものである.

\section{4.「英語口頭発表の仕方」の講義内容}

口頭発表では聴衆の理解が最重要であり，発表者は 理解してもらうための努力を徹底的にする必要があ る. 英語プレゼンテーションの構成は, 図10に示す ように, Introduction, Body, Conclusionの三拍子構成 で, “Tell'em Three Times Approach”である.すな

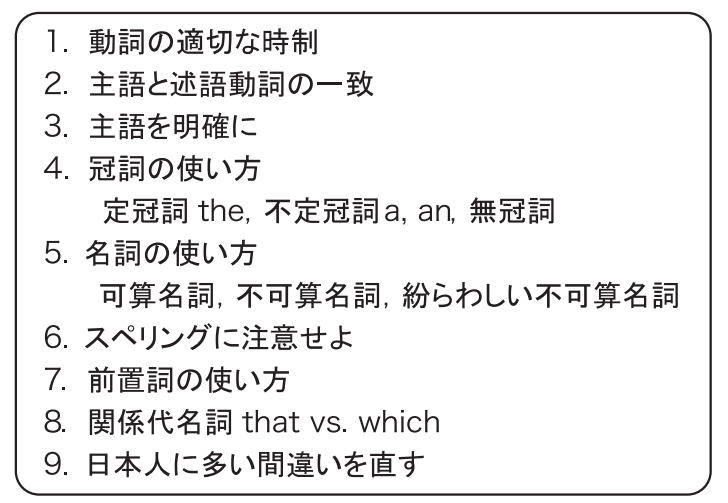

図 9 英文を書くときに心得ておくべき文法的事柄

\begin{tabular}{|c|}
$\begin{array}{c}\text { Basic Parts of a Presentation (英語は三拍子) } \\
\text { Introduction } \Rightarrow \text { Body } \Rightarrow \text { Conclusion }\end{array}$ \\
\hline $\begin{array}{c}\text { Tell'em Three Times Approach } \\
\text { (聴衆に同じことを } 3 \text { 回話す) }\end{array}$ \\
Introduction (序論) \\
Tell them what you will tell them. \\
Body (本論) \\
Tell them. \\
Conclusion (結論) \\
Tell them what you told them.
\end{tabular}

図 10 英語プレゼンテーションの構成

\section{Use eye contact.}

(聴衆の目を見ながら話せ, 後ろを向くな)

2. Develop a positive attitude and relaxed style.

（積極的な態度でしかもリラックスして）

3. Don't read your paper.

（自分の論文を読むな）

4. Don't memorize your paper.

（論文を暗記するな、そのまま話すな）

5. Be enthusiastic about the topic.

（発表テーマに対して情熱的になれ）

6. Don't hide behind a tangled web of technical terms. （技術用語を並べて逃げずにやさしく話せ）
わち, Introductionでは “Tell them what you will tell them.”, Bodyでは “Tell them.”, Conclusionでは “Tell them what you told them.”となる.

日本語の発表と異なり, 英語でのプレゼンテーショ ンのテクニック（IEEE版）は図11に示すようなポイン トが強調されており,これらを踏まえ, 講義・演習を行っ ている ${ }^{7)}$. 注目すべきポイントは 1 の「聴衆の目を見な がら話せ (アイコンタクトを取ること)」, 5 の「発表テー マに対して情熱的になれ (be enthusiastic)」である.

講義でカバーしている項目を図12に示す.

特に日本人が気をつけなくてはならないポイント は, 3 の「スライドの効果的な使い方」，4の「英語 の構造（わかりやすい英語表現）」，5の「わかっても らえる英語のしゃべり方」，7の「発表時のマナー・

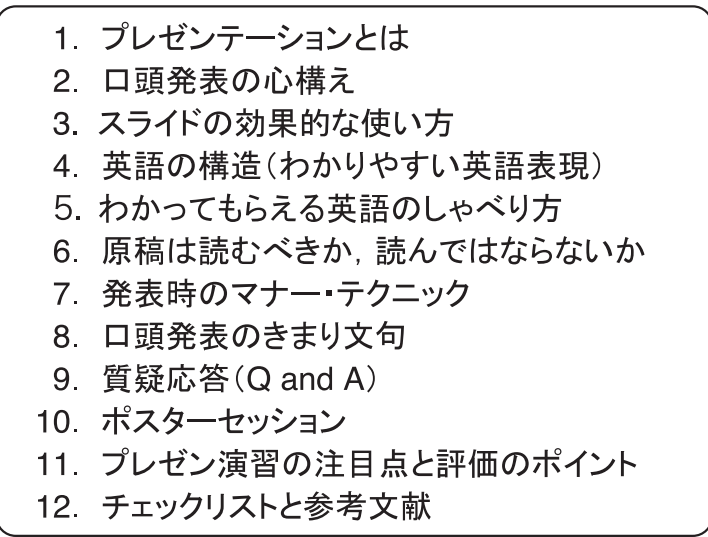

図 12 「英語口頭発表の心得」の講義内容

スライドは、ロ頭発表の内容を正確に伝達する重要な メディアである. 見やすく, わかりやすいスライドを作る

1. 口頭発表で使う図は, 論文中の図とは別に準備する

2. 口頭発表で使うスライドでは, 短い時間に聴衆が楽に 理解できることを主目的とする

3. できるだけ簡潔なものにして,「これだけはわかっても らいたいこと(take-home message)」のみを描く

(1) 1つのグラフの中には, 曲線は3本までとする

(2) data points を表す場合も, 3通りまでとする

(3) 説明的なものを加え, 印象を強くし, 短時間で理 解を助けるようにする

図 13 スライドの効果的な使い方

書き言葉と話し言葉は異なるので, 論文の英文をもとに した原稿では, 英語は硬すぎて聞いても理解できない

चु

・口頭発表は一回聞いただけで, 聞き手が気持ちよく 理解できるようなやさしい英語 (SVO構文)を使え -中学生でもわかる文法を使え

·聞き取りやすい(発音しやすい)単語を使え

·関係代名詞, 関係副詞は使うな

·能動態を用い, ストレートにものを言え

図 14 わかりやすい英語表現 
テクニック」，9の「質疑応答（Q＆A）」などである. 以下にこれらを説明する。

スライドの効果的な使い方の注意点を図13に示す. ここでのキーワードはtake-home message（これだけ はわかってもらいたいメッセージ) である.

図14に英語口頭発表向けのわかりやすい英語表現と は何かを示す．書き言葉と話し言葉は異なるので，論 文をもとにした原稿を読むと理解してもらえないこと がしばしば起こるので注意が必要である.

次に，実際の英語口頭発表のときに注意すべき点を 図15に示す. 英語での発表では日本語のときと異なり, アイコンタクトと質疑応答 (Q＆A) が非常に重要で ある. 若い日本人研究者・技術者はプレゼン後の質疑 応答が苦手な人が多い。これは英語の質問が聞き取れ ないことを恐れて，緊張してしまう場合が多いからで

\footnotetext{
1. 司会者に対し、紹介された後に礼を必ず述べること

2.「ただいま紹介いただきました○○です」と, 再度名 前を言ってはならない

3. 出だしの数行を暗記しておく

4. 本論では具体例をできるだけ入れる

5. 1つのsentenceは 20 words 以下にとどめる

6. 原稿を読みながら発表をするときには, 8〜10 秒に 1 回程度顔を上げて, 聴衆を数秒, 見渡すようにする (eye contact をきちんと取ること)
}

7. 英米人は質疑応答 (Questions \& Answers Session) を講演以上に重視しているので, その準備も必要

図 15 英語口頭発表で注意すべき点

Do not say "Pardon?" or "Could you repeat your question?" Instead you should say the following:

1. I couldn't hear you. Would you speak a little louder, please?

2. Would you speak up, please? I can't hear you.

3. I'm sorry. I did not understand your question. Could you kindly re-phrase it slowly?

4. I'm sorry. I did not understand what you meant. Can you simplify your question please?

5. Do you mind paraphrasing your question?

図 16 聞き取りにくい質問への答え方

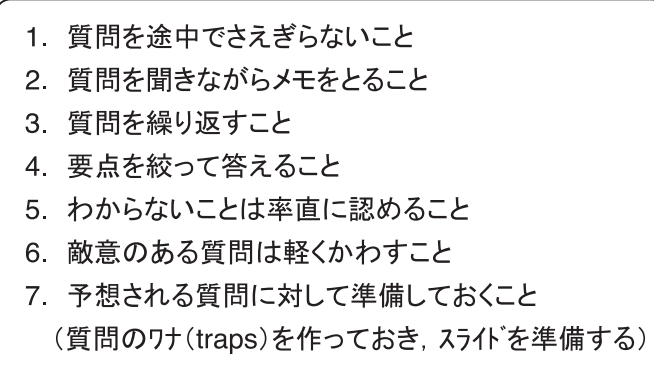

図 17 質疑応答 $(\mathrm{Q} \& \mathrm{~A})$ の指針
あろう。このような場合には, 質問を繰り返しても らうのに図16に示すような言葉 (rephrase, simplify, paraphrase）をうまく使って聞きなおす招寺よい。そ れでもわからないときには, 司会者 (chair) に助け てもらうようにするとよい.

Q\&Aの対応は, 図17に示す様 ${ }^{15)} に$ に分に準備をし て, 落ち着いて質問を聞いて, 自信を持って結論から 答えるようにすればよい。

\section{5. 外部ネイティブ講師による演習 $(\mathrm{B})$}

前半の講義 $(\mathrm{A})$ を履修した学生から, 英語運用能力 テスト（Proficiency Test）の結果を基に演習(B)の 履修者を選抜している。（夏学期10クラス, 冬学期 5 クラス, 10 人/クラス)

図18にプレゼンテーション演習の注目点と評価のポ イントを示す.ここで重要なのは, 同じテーマで 2 回 発表することである. 1 回目のプレゼンテーションで 指摘されたところを練り直し， 2 回目を行うことでよ りわかりやすい, 聞きやすい発表になる.

英語でのプレゼンテーションでは, eye contact, facial expression, gestures, enthusiasm等 のnon-verbal communicationが重要であるので, ネイティブ講師に これらを丁寧に指導してもらっている.

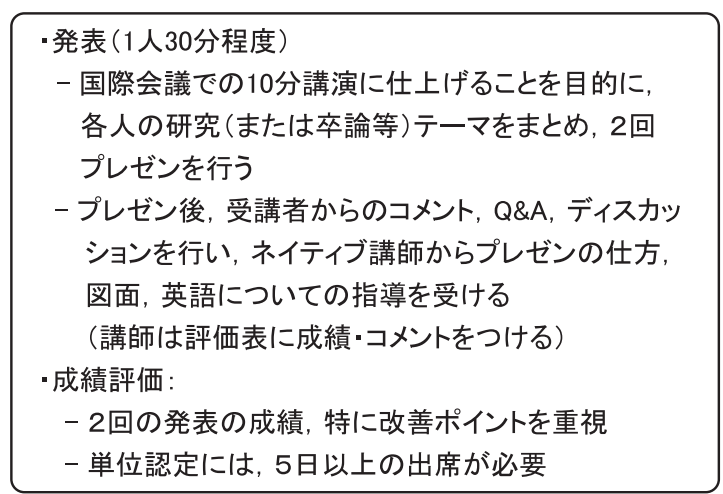

図 18 プレゼンテーション演習の注目点と評価のポイント

6. おわりに

2003年夏学期から 2006年冬学期の講義 (A)の受講者 数の経緯を表 1 に示す。単位取得者(レポート提出者)

表 1 講義（A）の受講者数経緯

\begin{tabular}{|c|cccc|}
\hline 年度・学期 & 登録者数 & & 単位取得者数 \\
\hline 2003 年度夏 & 181 & $\Rightarrow$ & $108(60 \%)$ \\
2003 年度冬 & 51 & $\Rightarrow$ & $34(67 \%)$ \\
2004 年度夏 & 156 & $\Rightarrow$ & $87(56 \%)$ \\
2004 年度冬 & 59 & $\Rightarrow$ & $34(58 \%)$ \\
2005 年度夏 & 169 & $\Rightarrow$ & $115(68 \%)$ \\
2005 年度冬 & 37 & $\Rightarrow$ & $28(76 \%)$ \\
2006 年度夏 & 251 & $\Rightarrow$ & $158(63 \%)$ \\
2006 年度冬 & 70 & $\Rightarrow$ & $47(67 \%)$ \\
\hline 合 計 & 974 & $\Rightarrow$ & $611(63 \%)$ \\
\hline
\end{tabular}


- ポイントが分かり易くまとめられてよかった. 今後論文. プレゼンを作る際に非常に参考になると思う.

·非常に貴重な講義でした. 今後に活かします.

・とても有効でした. 特に博士課程に入り英語でのコミュニ ケーションの能力の必要性を実感していたときだったの で楽しめました。

・講義期間中に学会があり発表の心得は非常に役立った - Introductionにresultを含めるときいて正直困惑しました ・ このような形式の授業がもっと早い時期に受講できれば 自分の英語ももう少しましになっていたかと思いました.

図 19 講義に関する受講生コメント

\begin{abstract}
·実際にプレゼンをすることはすごくいい練習になると思います 発音のくせ等を指摘してもらい参考になりました. ジェスチャー や身のおき方(前を向く)などをわかりやすく示してくれました. ·他の学生の発表を聞いて質問やフィードバックをするのも非常 に勉強になりました。

日本人には無い視点で指摘をしてくださったので非常に勉強に なりました.

とても勉強になりました. 2 回発表できたことが非常に良かった ですし, 改良でき, それに関するコメントももらえた.

·発表は1回ではやりっ放しになってしまうから2回あってよかった. - This is the first time to have my presentation checked. So, it was very efficient. l'll recommend it to others.
\end{abstract}

図 20 演習に関する受講生コメント

は登録者の $60 \%$ 程度である。工学系研究科には毎年修 士課程に約 800 人, 博士課程に約 300 人の入学者があり, 夏学期は修士 1 年生の登録が多いが，レポートの論文 が未提出のため未受験となる学生も多い.これらの学 生は後に履修しなおす場合が多い.

講義 $(\mathrm{A})$ に関する受講生のコメントを図19に示す. 今までこのような講義がなかったこともあり，多くの 受講生が「役に立った」と評価している。 しかしなが ら単位を取得した学生の多くは「英語論文の書き方」 の入り口にやっと立ったところで，今後続けて訓練す ること（論文執筆・修正を繰り返すこと）により英語 を母国語とする研究者・技術者に理解してもらえる英 語論文が書けるようになると期待している.

2003年夏学期から 2006 年冬学期の演習 (B) の受講者 数の経緯を表 2 に示す. 英語能力運用テストで選別し た学生を受講者としているため, 単位取得者は登録者 の $80 \%$ 程度となっている.

図20に演習(B)に関する受講生のコメントを示す. 英語のプレゼンテーションは初めての学生がほとんど で, 発音, ジェスチャー, 発表時の姿勢などについ ての指摘が勉強になったと報告している。また 2 回発 表をすることで，自信を持ってプレゼンできるように なった学生が出てきた.「ネイティブ講師への満足度」, 「講義を友人に推薦したいか」に関するアンケートに 対しては, どちらも $97 \%$ 学生が満足している, 推薦
表 2 演習（B）の受講者数経緯

\begin{tabular}{|c|c|c|c|}
\hline 年度・学期 & 登録者数 & & 単位取得者数 \\
\hline 2003 年度夏 & 48 (5クラス) & $\Rightarrow$ & $45(94 \%)$ \\
\hline 2003 年度冬 & 27 (5クラス) & $\Rightarrow$ & $22(81 \%)$ \\
\hline 2004 年度夏 & 47 (5クラス) & $\Rightarrow$ & $39(83 \%)$ \\
\hline 2004 年度冬 & 34 (5クラス) & $\Rightarrow$ & $19(59 \%)$ \\
\hline 2005 年度夏 & 114（10 クラス） & $\Rightarrow$ & $99(87 \%)$ \\
\hline 2005 年度冬 & 33 (5クラス) & $\Rightarrow$ & $26(79 \%)$ \\
\hline 2006 年度夏 & 118 (10 クラス $)$ & $\Rightarrow$ & $93(79 \%)$ \\
\hline 2006 年度冬 & 52 (5クラス) & $\Rightarrow$ & $45(86 \%)$ \\
\hline 計 & 473 & $\Rightarrow$ & $388(82 \%)$ \\
\hline
\end{tabular}

したいとしている. 以上からわかるように, 講義と演 習を組み合わせることにより, 学生の英語口頭発表の スキルアップに効果が大きいことがわかった.

\section{参 考 文 献}

1 ) H.M. Weisman: "Basic Technical Writing” (6th Ed.) Macmillan Publishing Co., New York, 1992

2 ) W.S. Pfeiffer: "Pocket Guide to Technical Writing," (3rd Ed.) Pearson Education, New Jersey, 2004

3 ) 小野義正: ポイントで学ぶ科学英語論文の書き方, 丸善, 2001

4 ) 小野義正: 本当に役立つ科学技術英語の勘どころ, 日刊工業新聞社, 2007

5 ) D.E. Waters, G.C. Waters : "Scientists Must Speak-Bringing Presentations to Life," Routledge, Taylor \& Francis, New York, 2002

6 ) M. Alley : "The Craft of Scientific Presentations Critical Steps to Succeed and Critical Errors to Avoid," Springer Science, New York, 2003

7 ）小野義正 : ポイントで学ぶ英語口頭発表の心得, 丸善, 2003

8 ）中村輝太郎(編著)：英語口頭発表のすべて, 丸善, 1982

9 ）志村史夫：理科系のための英語プレゼンテーショ ンの技術, ジャパンタイムズ, 1996

10）小野義正：『大学院講義：科学技術英語』一英語コ ミュニケーション力向上策 : 東大工学系研究科で の講義と成果を例として, 平成18年度 工学・工業 教育研究講演会講演論文集, 社)日本工学教育協会, pp. $304-305,2006$

11）小野義正, 森村久美子：『大学院講義：科学技術英 語』 II 英語口頭発表の仕方 - 英語コミュニケー ション力向上策 : 東大工学系研究科での講義と成 果を例として, 平成19年度 工学・工業教研究講演 会講演論文集, (社)日本工学教育協会, pp.480-481, 2007

12) A.J. Leggett: "Notes on the writing of scientific 
English for Japanese physicists," 日本物理学会 誌, 21, pp.790-805, 1966.（日本語訳は日本物理 学会・編集：「科学英語論文のすべて(第 2 版)」, 丸善, 第 4 章, pp.149-183「科学英文執筆につい て覚書」, 1975)

13）木下是雄：理科系の作文技術, 中央公論社, 第 5 章, 第 6 章, pp.75-100, 1981

14）外山滋比古：英語の発想 -日本語の発想, 日本放 送出版協会, pp.10-13, 1992

15) J.C. Garland: “Advice to beginning physics speakers," Physics Today, July 1991, pp.42-45, 1991. (日本語訳は小林俊一(訳)：「初めて学会で 登壇する君へ」, パリティ, Vol.7, No.3, pp.66-71, 1992)

\section{著 者 紹 介}

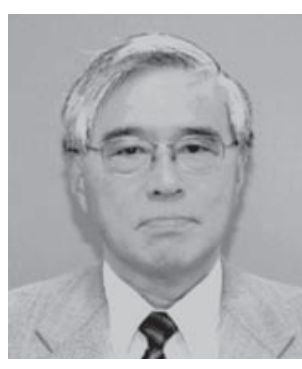

\section{小野 義正}

理学博士

1977年東京大学理学系大学院物理学専門 課程博士課程修了, イリノイ大学, ケース・ ウェスタン・リザーブ大学物理学科でポ スドク（仁科記念財団海外派遣研究員と して).

1982年(侏)日立製作所日立研究所に入社し， プリンタ, ディスプレイの研究を経て 企画室主任研究員, 国際交流室長を歴任. 1993年同社基礎研究所に異動し, テクニ カルサポートセンター長として, 研究管 理, 国際会議開催, 科学技術英語の指導. 2002年同社研究開発本部に異動. 研究戦 略統括セン夕担当部長として, 国家プロ ジクト・ナノテクノロジー推進, 科学技 術英語を担当.

2005年 7 月から東京大学大学院工学系研 究科工学教育推進機構 国際化推進室特任 教授. 科学技術英語担当.

所属学協会: 日本工学教育協会, 応用物 理学会, 日本物理学会, 日本機械学会, IEEE，アメリカ物理学会など.

科学・技術英語に関する著書 (4 冊)

(yaono@t-adm.t.u-tokyo.ac.jp) 